\title{
PROCESSING CHARACTERISTICS AND PROPERTIES OF THE CELLULAR PRODUCTS MADE BY USING SPECIAL FOAMING AGENTS
}

\author{
Tomasz Garbacz ${ }^{1}$, Ludmila Dulebova ${ }^{2}$ \\ ${ }^{1}$ Lublin University of Technology, Department of Polymer Processing, Lublin, Poland, \\ e-mail: t.garbacz@pollub.pl \\ ${ }^{2}$ Technical University of Kosice, Department of Technologies and Materials, Kosice, Slovakia, \\ e-mail: ludmila.dulebova@tuke.sk
}

Keywords: thermoplastic polymers, cellular extrusion, blowing agents

\begin{abstract}
The paper describes the manufacturing process of extruded products by the cellular extrusion method, and presents specifications of the blowing agents used in the extrusion process as well as process conditions. The process of cellular extrusion of thermoplastic materials is aimed at obtaining cellular shapes and coats with reduced density, presenting no hollows on the surface of extruder product and displaying minimal contraction under concurrent maintenance of properties similar to properties of products extruded by means of the conventional method. In order to obtain cellular structure, the properties of extruded product are modified by applying suitable plastic or inserting auxiliary agents.
\end{abstract}

\section{ASPECTS OF CELLULAR EXTRUSION}

During the extrusion process, blowing agents are exposed to the same conditions as the processed plastics, i.e. to heating, compression, homogenizing treatment, which are carried out before gas emission. Inert gases and low-boiling liquids may dissolve in the plasticized material, whereas porophor melting rate increases along with the increased mixing intensity and gas pressure. Proper process conditions are usually selected during the experiment.

Blowing agents used during cellular extrusion of plastics may display exothermic or endothermic decomposition characteristics $[1,2,3]$.

Blowing agents have endothermic decomposition characteristics; generation of gas during processing is rapidly stopped when the energy flow is cut off. The application of such blowing agents considerably shortens the cooling time. Examples belonging to this group include especially bicarbonates, e.g. sodium bicarbonate, ammonium bicarbonate and 2Hydroxypropanetricarboxylic acid [3-6]. Different types of extruder heads are used in the cellular extrusion process. Straight mandrel, direct flow extruder heads for solid plastics are usually applied in order to obtain cellular products with small cross-sectional fields and thin walls. Channels in extruder heads of this type can be corrected relatively easily $[1,6,8]$.

During decomposition, exothermic porophors release more energy than it is actually required in this reaction. The initiated decomposition proceeds spontaneously, even after energy cut-off. For this reason, products extruded with the use of this type of agents must be intensely cooled for a long time to prevent strains. This may be the cause of local overheating and generation of irregular cellular structure of the product $[1,2,6]$. 
The main representatives of this group of agents include hydrazides, e.g. sulfohydrazide and AZO compounds, for instance azodicarbamide. This compound is widely used in cellular extrusion of polyethylene, polyvinyl chlorine, polystyrene and polyamide [4].

Compared to porophors with exothermic characteristics, porophors with endothermic characteristics significantly shorten cooling time of the product, which also leads to shortening of the manufacturing cycle. Basic materials for porophors with endothermic decomposition characteristics are bicarbonates and citric acid. As these substances are used as food additives, their use poses no problem $[3,8,9]$.

In the cellular extrusion process, porous structure is formed by mixing the thermal decomposition products, chemical blowing agent with the material or inert gas brought to the plastic injection molding plasticizing in the system or directly into the formation. Blowing agents (porophors) are a source of gas which diffuses into the polymer and causes the cells. However, this does not mean that these additives must be in the form of gases, since such chemical agents are often porous solids or liquids, which release gaseous substances only in a chemical reaction. For a porous material of appropriate structure and quality a blowing agent must be carefully selected, depending on processing conditions, type of polymer, and the assumed parameters of the final product. The type and amount of added blowing agents have an effect on the final density of the porous material and on determining to determine the choice of a comparison method. In order to achieve a high degree of so-called comparison physical blowing agents (gases, volatile liquids) are used. Chemical blowing agents are applied where it is necessary to maintain low levels of capital expenditures for equipment and machinery in the process. The essence of this process is the introduction of the plastic materials (support), most of them are concentrated $(5-70 \%$ concentration) or powders [3-6]. The difference between the process of physical and chemical materials is less associated with the course of the process than the dosing of porophors to polymers $[7,9]$.

\section{EXPERIMENTAL WORK}

The aim of the conducted research was to discover the influence of modifying HDPE with selected agents that is a blowing agents, in the course of the extrusion process, inclusive of determination how the modification affects selected physical properties and properties of the surface of HDPE extrusion product. Another objective was the assessment of the examined polymer in terms of required conditions and the properties of table topcoats. The article presents the specification of the cellular extrusion process of thermoplastics. In the research, endothermic chemical blowing agents in the amount of $0.6 \%$ by mass were used.

Extrusion of plastics which involves the use of blowing agents, results in obtaining new, modified physical and technological properties of extruder products $[3,6,8]$. These especially include reduced density of the product, minor shrinkage, enhanced noise suppressing and insulation properties, increased fire resistance, possible utilization after use. Inspection of selected physical, mechanical and usable properties of topcoats manufactured in the process of extrusion coating of cellular plastics, comprised part of a larger research project.

The extruding process was carried out with the use of a single-screw extruder, type W-25 with the screw diameter of $\mathrm{D}=25 \mathrm{~mm}$ (Fig.1). The plasticizing unit was equipped with four heating 
zones. The process line was composed of the extrusion coating head, vacuum calibrator, the cooling bath and the remaining process line components.

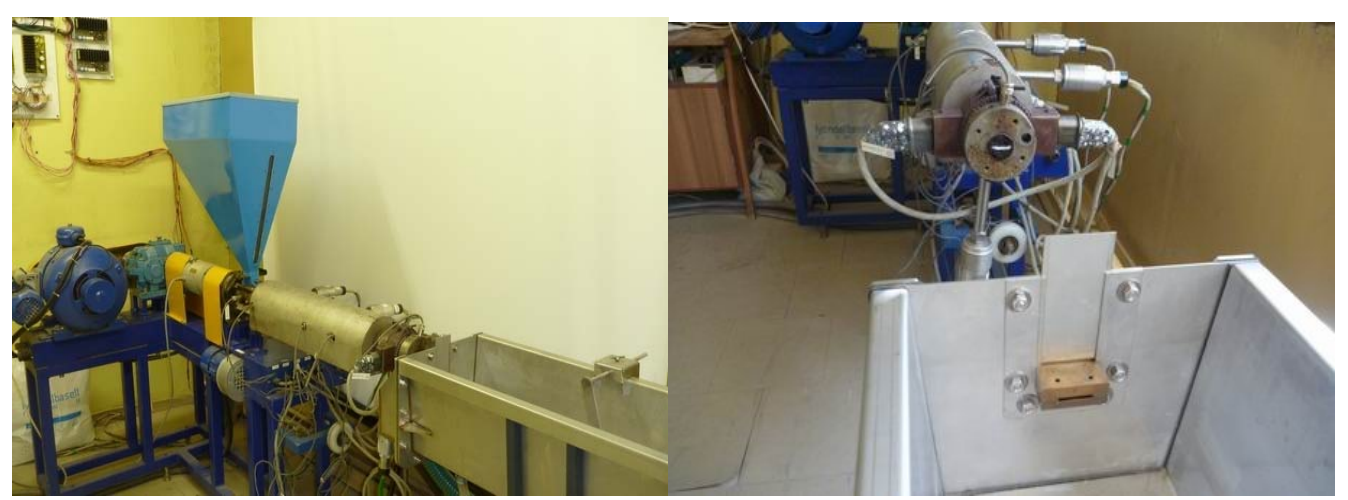

Figure 1:View of technological line section for cellular extrusion process.

The tape extrusion head used during the tests, is equipped with a heating zone of the assumed ring electric heater, sensor measurements of temperature and pressure and the second temperature sensor - thermocouple. The head has a removable slotted nozzle to produce the tape. Width of the nozzle, used in the studies is $22.00 \mathrm{~mm}$ and its height $=1.40 \mathrm{~mm}$.

The study uses a removable calibration system, cooling system and exhaust belt. The research employed a cooling dip bagasse. During the process of extrusion the temperature set points in individual zones of the heating of the plasticizing unit amounted to $130{ }^{\circ} \mathrm{C}, 160{ }^{\circ} \mathrm{C}$, and $180{ }^{\circ} \mathrm{C}$.

Torque, speed, temperature and pressure distribution in the different zones of heating and plasticizing extrusion head during testing was measured and adjusted using a monitoring program foaming extrusion process.

HDPE manufactured by Lyondell Basell Industries, having a trade name Hostalen 4731 M, was used in the study on cellular extrusion process. This plastic has density of $947 \mathrm{~kg} / \mathrm{m}^{3}$ and hardness of $59^{\circ} \mathrm{ShD}$ (according to material list).

Considering the nature of the conducted tape extrusion process, among others the temperature of the plastics in the plasticizing unit and the extruder head, plastic pressure, cooling conditions and geometrical dimensions of the obtained cable topcoat, blowing agents which have endothermic decomposition during the extrusion coating process should be used. In accordance with the established research program, the plastics intended for extrusion was modified by introducing the blowing agent during the stirring process.

In the research presented in the article, a blowing system with the trade name Hydrocerol CT 550, produced by Clariant Masterbatch Division was used. It is a blowing system with endothermic decomposition characteristics, taking the form of granules ranging from 1.4 to 1.5 $\mathrm{mm}$ in diameter. Hydrocerol CT 550 contains $70 \%$ of the mass of the blowing agent with initial decomposition temperature of $150^{\circ} \mathrm{C}$. In the presented research, Hydrocerol CT 550 was dispensed as $0.3 \%$ to $0,6 \%$ of the mass. When using blowing agents of this type, it is important that porophor's decomposition temperature is exceeded under proper processing conditions. In the cellular extrusion process, temperature of the extruder head should approximate decomposition 
temperature of the blowing agent. The degree of porosity of the product may be reduced or increased by regulation of the screw's rotational speed.

\section{EXPERIMENTAL RESULTS}

The type and amount of the metered foaming agent in the research was chosen in such a way that at the assumed conditions of the extrusion process, the received product has a solid surface and foamed core. Following cellular extrusion tests, selected physical properties of the manufactured power cables were examined. The article presents selected results of examination of changing the rotational speed of the extruder, melt flow rate (MFR) and microscopic structure. The studies of density and foaming degree hardness, tensile strength were made and are presented in Table 1.

Table 1:Results of measuring of cellular tape modified by a blowing agent.

\begin{tabular}{|c|c|c|c|c|c|}
\hline No. & $\begin{array}{c}\text { The contents of } \\
\text { active agent [ \%] }\end{array}$ & $\begin{array}{c}\text { Density } \\
\boldsymbol{\rho}\left[\mathbf{~ k g / \mathbf { m } ^ { 3 } ]}\right.\end{array}$ & $\begin{array}{c}\text { Degree of } \\
\text { porosity [\%] }\end{array}$ & $\begin{array}{c}\text { Hardness } \\
{\left[{ }^{\mathbf{0}} \mathbf{S h A} \text { ] }\right.}\end{array}$ & $\begin{array}{c}\text { Tensile } \\
\text { strength } \\
\text { [MPa] }\end{array}$ \\
\hline 1. & 0.0 & 947 & 0 & 60 & 11.50 \\
\hline 2. & 0.2 & 850 & 19 & 59 & 10.40 \\
\hline 3. & 0.4 & 740 & 25 & 58 & 10.00 \\
\hline 4. & 0.6 & 710 & 27 & 58 & 9.50 \\
\hline
\end{tabular}

The dependence of the changing the rotational speed of the extruder on materials and the dependence of MFR on contents of blowing agent in processing HDPE, during conduct research is shown in Fig. 2.
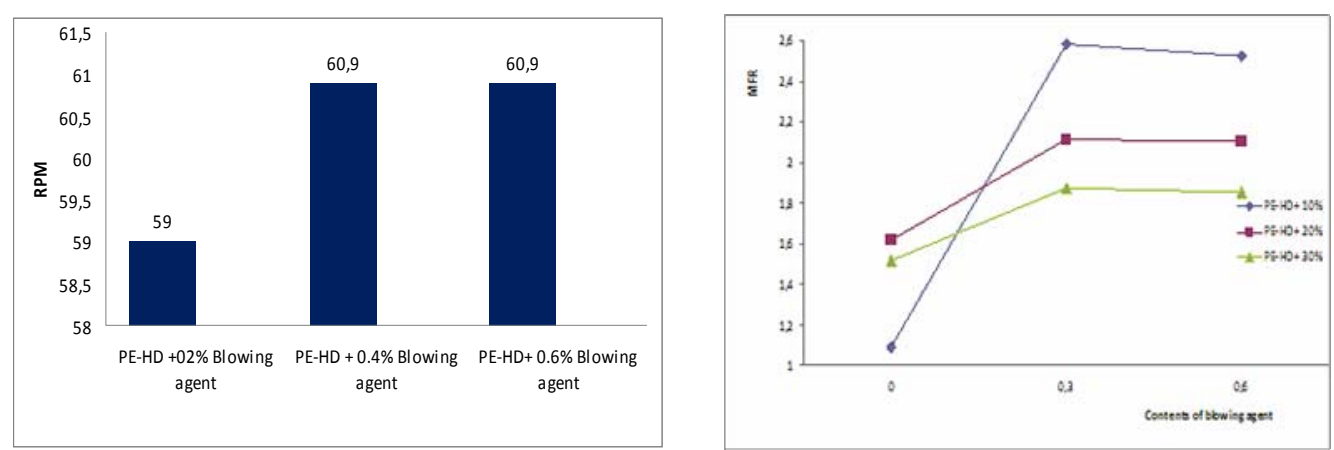

Figure 2:The dependence of the changing the rotational speed of the extruder on materials and of MFR on contents of blowing agent in processing HDPE.

The view of the microscopic position and microscopic image of the cross section of the cellular tape polymer of the amount of the blowing agent $0.4 \%$ mass (magnified $50 \mathrm{x}$ ) is shown in Fig. 3. Microscopic image of the cross section of the cellular tape polymer of the amount of the blowing agent $0.4 \%$ mass (magnify $50 \mathrm{x}$ ) is shown in Fig.4. 

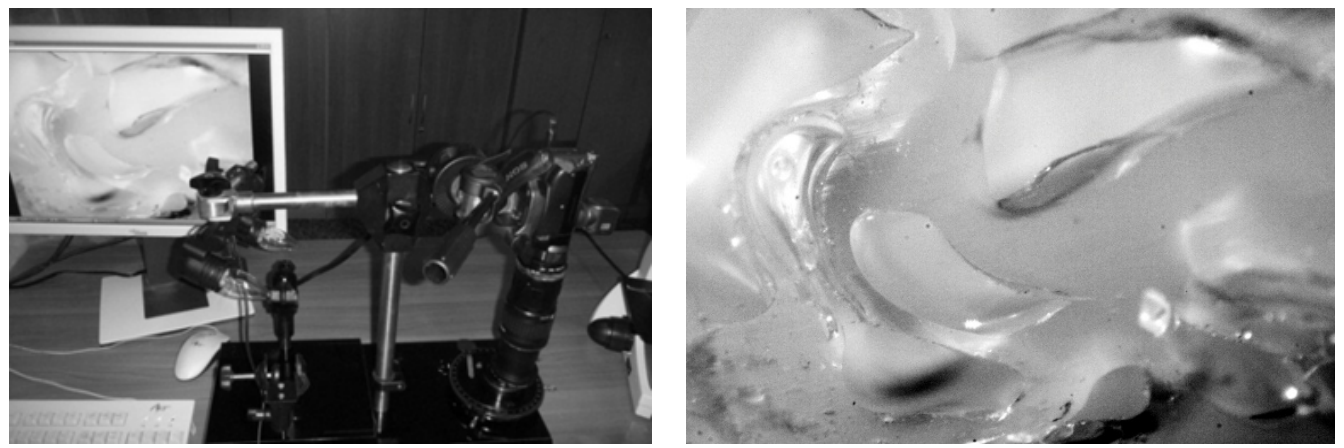

Figure 3: View of the microscopic position and microscopic image of the cross section of the cellular tape polymer of the amount of the blowing agent $0.4 \%$ mass.
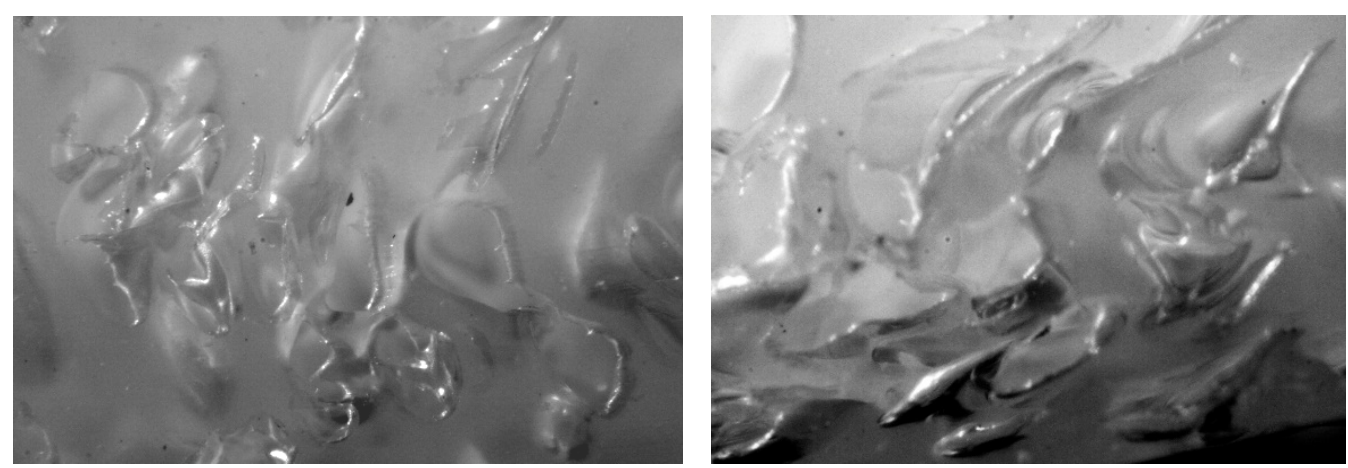

Figure 4:Cross-sectional view of a cellular product, with $0.6 \%$ content of the blowing agent.

\section{CONCLUSIONS}

Increasing content of the blowing agent, being a mixture of chemical compounds with endothermic decomposition characteristics results in reduced density of the cellular product are presented in the article. The cellular product's density is determined by the ratio of solid to gaseous phase and the size and shape of microcells. As a result of increased temperature in the plasticizing unit and the extruder head, sodium bicarbonate and citric acid, comprising the blowing agent, undergo decomposition in a proper temperature, and there emerge numerous micro-bubbles which, due to pressure and surface development, immediately dissolve in the surrounding plastic. The emerging micro-cells are filled in with both air and gases, increasing the volume of polyethylene. This results in reduced density of the obtained cellular product.

The degree of porosity, being a property determining the volume of the gaseous phase in the cellular product, at the same time determines the value by which the density of the product is reduced. 
Mechanical properties, including tensile strength of the cellular product are affected by shape, orientation and macromolecule bonds. Smaller number of crosswise bonds in the cellular plastic results in reduced strength of the product.

Below, we present important conclusions from the conducted examination of cellular cable coatings:

- The manner of dispensing the blowing agent into the plastic used in the process proved to be effective. No visual changes and no changed properties of the examined product have been observed, resulting from such manner of dispensing and mixing HDPE with the blowing agent Hydrocerol CT 550.

- Quality of the obtained coating, taking into account criteria such as degree of porosity, density and other examined physical, mechanical and usable properties is assessed as very good. Density of the obtained coating was up to $710 \mathrm{~kg} / \mathrm{m}^{3}$ and its degree of porosity was up to $0.6 \%$.

- The use of a blowing agent with endothermic decomposition characteristic dispensed from 0.3 to $0.6 \%$ of the mass, allows to obtain a product meeting expectations and objectives of the conducted research.

\section{ACKNOWLEDGMENTS}

This paper is the result of the project implementation FP7-PEOPLE-2010 -269177 supported by the international project realised in the range of Seventh Frame Programme of European Union.

\section{REFERENCES}

[1] Garbacz T.: Properties of triple-layered PVC coatings synthesized in the microporecoextrusion method. Polimery 2011, 56, 2, 129.

[2] Li. Q, Matuana L.M.: Foam extrusion of high density polyethylene/wood-flour composites using chemical foaming agent. Journal of Applied Polymer Science 2003, 88, 3139.

[3] Sikora, J.W.: Selected problems of polymer extrusion. Wydawnictwo Naukove WNGB, Lublin ,2008.

[4] Greškovič F., Dulebová L', Varga J.: Technológie spracovania plastov. Vstrekovanie. SjF TU v Košiciach, Košice, 2010.

[5] Klepka T.: Efektywność wytłaczania polimerowych specjalnych warstw slizgowych utworzonych w procesie wytłaczania. Polimery 2004, 7, 123.

[6] Garbacz. T.: Structure and properties of cellular thin-walled cable coatings. Polimery 2012 57, 11-12, 91

[7] Gondár E., Ulík J. : Properties of polethylene regranulate obtained during the production of fuel tanks of cars. Chemické listy2005, 99, 32

[8] Garbacz T., Tor A:Effect of porophor content on the useful properties of external coatings of cables obtained by foaming extrusion. Polimery 2007, 52, 4, 286. 
SCIENTIFIC PROCEEDINGS 2012, Faculty of Mechanical Engineering, STU in Bratislava

Vol. 20, 2012, pp. 74-80, DOI: 10.2478/v10228-012-0012-9

[9] Суберляк О.В., Шаповал Й.М., Красінський В.В.: Епокси-новолачні композиції. Вплив природи наповнювача на фізико-механічні властивості. Хімічна промисловість України 2008, 2, $45-48$. 